\title{
Trends in Fertilizer Consumption and Foodgrain Production in India: A Co-integration Analysis ${ }^{\#}$
}

\author{
L. M. Punith Kumar ${ }^{1 *}$ and M. Indira ${ }^{2}$
}

'Project Fellow, UGC UPE FA-II, University of Mysore, Mysore, Karnataka, India ${ }^{2}$ Professor of Economics, Department of Economics, Manasa Gangothri, University of Mysore, Mysore, Karnataka, India

\begin{abstract}
Food grain production in India has increased considerably from 50 MT in 1951 to 266 MT by 2013-14. Introduction of green revolution, modernization of agriculture, encouragement to research and extension in agriculture are some of the factors contributed for this growth. However, this is accompanied by considerable increase in the usage of chemical fertilizers starting with the introduction of green revolution in 1960s leading to unsustainable agriculture. The Green Revolution was a technology package and it contains technical component of improved high yielding varieties of two staple cereals (rice and wheat), irrigation and use of fertilizers, pesticides, and better management practices. The high yielding varieties demanded more usage of fertilizers and it is supported by the subsidy policy on fertilizers. In the early 1980s, India introduced New Economic Policy (NEP) which has opened up the economy to privatization and globalization. In the globalized economy agricultural sector became more commercial and production is oriented to export market. This also led to increase in fertilizer consumption. The main objective of this paper is to analyse the trends in the consumption of chemical fertilizers and food grain production in India and to identify the relationship between these two. The study is based on the secondary data and Co-integration Technique and CAGR are used to analyse the trends. The analysis revealed long run relationship between these two variables in India. Encouraged by the increased production, farmers have increased fertilizer consumption without considering the environmental consequences and sustainability of agriculture.
\end{abstract}

Keywords: Agriculture, Fertilizer, Consumption, Development

\section{Introduction}

With the growing global environmental issues and climate change, sustainable agriculture became an important issue for the planners. Therefore the agricultural policies all over the world are aiming at attaining sustainable agriculture.

India was facing the problem of food shortages during the period of independence and imported foodgrains from the other countries. However with focused efforts, the country could attain self-sufficiency and agricul- ture production has increased considerably. The total foodgrain production in India was 52 MMT during 1951-52, and it has increased to 264 MMT in 2013-14. This was attained through the agricultural policy and government's interventions of providing agricultural inputs like credit, seeds and fertilizers at subsidized rates.

Considerable increase in the usage of chemical fertilizers started with the introduction of green revolution in 1960s. The Green Revolution is a technology package and it contains improved varieties of seeds, chemical

*Email: punithmayanna89@gmail.com

"Modified and revised version of the paper, presented in the $2^{\text {nd }}$ International Conference on Inclusive Economic Growth and Sustainable Development, SDMIMD, November 2016. 
fertilizers, pesticides and irrigation. The high yielding varieties demanded more usage of fertilizers and it is supported by the subsidy policy on fertilizers. In the early 1980s, India introduced New Economic Policy (NEP) which has opened up the economy to privatization and globalization. In the globalized economy agricultural sector became more commercial and production is oriented to export market. This also led to increase in fertilizer consumption.

Chemical fertilizers are major inputs of scientific agriculture. India is one of the major countries in the production and consumption of fertilizers. The usage of chemical fertilizers with High Yield Verities of seeds and irrigation, increases the agricultural production and it helps to achieving the self sufficiency of food grains (Department of Fertilizer GOI, 2013).

Several researchers have analysed the impact of agricultural policy on fertilizer consumption, usage of chemical fertilizers, relationship between the use of chemical fertilizers and the food grains production etc. Singh (2013) has analyses the consumption of chemical fertilizers and food grain production in India. The study is based on secondary data and examined the trends in fertilizer consumption and also food grain production. Fertilizers play a major role in the modern agriculture. The study has identified that there is a continuous increase in the fertilizer production and also consumption, the country has achieved the near self sufficiency of Nitrogen and Phosphorus fertilizer. The study has suggested that in order to achieve the self sufficiency of food grain, the availability of fertilizer at affordable prices is very necessary or prerequisite.

Hossain and Singh (2000) examined the trends in the fertilizer consumption, changes in the government policies regarding fertilizer sector and its impact on prices of fertilizers, crop yield responses to fertilizer consumption, factors influencing the fertilizer consumption etc. The study has attempted on future projections of consumption of chemical fertilizers and also food grain production.

Mazid and Khan (2015) analysed the usage of bio fertilizer in agriculture in India. The study used linear regressing model to identify the relationship between the usage of bio fertilizers and agriculture production. The result shows there is a positive relationship between those variables. The study suggested that usage of bio fertilizer is very useful way to achieve sustainable agriculture compared to chemical fertilizers.

With this back ground, the present paper makes an attempt the analyse the linkages between chemical fertilizer consumption and the food grain production, the consequences of usage of chemical fertilizers on land degradation and review the efforts of the Government of India to promote sustainable agriculture.

\section{Objectives}

1. To identify trends in food grain production in India.

2. To identify the relationship between fertilizer consumption and food grain production in India.

\section{Methodology}

The study is based on secondary information. The data is collected from various sources such as planning Commission report, economic survey, annual reports of agriculture and other reports published by the Government of India. Compound Annual Growth Rate (CAGR) has been calculated to analyse the trends in fertilizer consumption and food grain production in India. The study has used Co-integration and Granger Causality techniques to identify the relationship between chemical fertilizer consumption and foodgrains production.

\subsection{Co integration and Granger Causality Techniques}

Co-integration between fertilizer consumption and food grain production from 1981-82 to 2013-14 was estimated by Co-integration and analysis. The Granger Causality test has been used to identify the causality between these two variables.

In the time series analysis, first and foremost step is to check whether the data under consideration is stationary or not. To check the level and stationarity of variables, ADF test is used in this paper. 


\subsection{Augmented Dickey- Fuller (ADF) Test}

$\Delta \mathrm{Yt}=\beta 1+\beta 2 \mathrm{t}+\delta \mathrm{Yt}-1+\sum_{i=1}^{M} \alpha 1 \Delta \mathrm{Yt}-1+\varepsilon \mathrm{t}$

Where $\varepsilon t$ is a pure white noise error term and Where $\Delta \mathrm{Yt}-1=(\mathrm{Yt}-1-\mathrm{Yt}-2), \Delta \mathrm{Yt}-2=(\mathrm{Yt}-2-\mathrm{Yt}-3)$ etc. (Gujarati, D. M. \& "Sangeetha 2007). "The number of lagged difference terms to include is often determined empirically. In ADF we test whether $\delta=0$ and ADF test follows the same asymptotic distribution as the DF statistics, so the same critical values can be used" (Gujarati, D. M. \& "Sangeetha 2007).

\subsection{Johansen Juselius Co-integration Test}

The equation used for co-integration test is as follows (Gujarati, D. M. \& "Sangeetha 2007).

$\mathrm{yt}=\beta_{0}+\beta_{1} \mathrm{Z}_{\mathrm{t}}+\mathrm{e}_{\mathrm{t}}$

$\beta_{0}$ and $\beta_{1}$ Co-integrating parameters

\subsection{Granger- Causality Test}

$\mathrm{Yi}=\alpha 0+\sum_{j=1}^{M} \beta \mathrm{Yt}-\mathrm{j}+\sum_{i=1}^{n} \delta \mathrm{Xt}-1+\mu 1$
If Xt Granger Causality, Yt, then the current values of Yt are determined by past values of Xt-1 (Gujarati, D. M. \& "Sangeetha 2007).

\section{Trends in Food Grains Production and Fertilizer Consumption in India}

Along with other factors like the seed, availability of irrigation and the weather, supply of micro nutrients through fertilizers influences output. Fertilizers supplement the soil nutrition that is lost in the process of cultivation. As observed earlier soil nutrition mining has resulted in negative nutrition balance in several parts of the country and the negative balance is highest in Potash (Tandon, 2007). Kinekar (2011) identified that imbalanced usage of chemical fertilizer is one of the major reasons for stagnation in agriculture production.

The following Table 1 depicts the trends in consumption of chemical fertilizers and the food grain production in India before and after the announcement of Agricultural Policy 2000.

Table 1. Trends in Fertilizer consumption and Foodgrain Production in India

\begin{tabular}{llllll}
\hline Year & $\begin{array}{l}\text { Fertilizer } \\
\text { Consumption }\end{array}$ & $\begin{array}{l}\text { FoodGrains } \\
\text { Production }\end{array}$ & Year & $\begin{array}{l}\text { Fertilizer } \\
\text { Consumption }\end{array}$ & $\begin{array}{l}\text { FoodGrains } \\
\text { Production }\end{array}$ \\
\hline \multicolumn{3}{l}{ Before the } & Announcement of Agricultural Policy & & After the Announcement of Agricultural Policy \\
\hline $1986-87$ & 86.45 & 143.42 & $2000-01$ & 167.02 & 196.81 \\
$1987-88$ & 87.84 & 140.35 & $2001-02$ & 175.39 & 212.85 \\
$1988-89$ & 110.40 & 169.92 & $2002-03$ & 160.94 & 174.78 \\
$1989-90$ & 115.68 & 171.04 & $2003-04$ & 167.98 & 213.19 \\
$1990-91$ & 125.46 & 176.39 & $2004-05$ & 183.99 & 198.36 \\
$1991-92$ & 127.28 & 168.38 & $2005-06$ & 203.4 & 208.59 \\
$1992-93$ & 121.55 & 179.48 & $2006-07$ & 216.51 & 230.78 \\
$1993-94$ & 123.66 & 184.26 & $2007-08$ & 225.70 & 234.47 \\
$1994-95$ & 135.63 & 191.5 & $2008-09$ & 249.09 & 218.11 \\
$1995-96$ & 138.77 & 180.42 & $2009-10$ & 264.86 & 244.49 \\
$1996-97$ & 143.77 & 199.43 & $2010-11$ & 281.22 & 259.29 \\
$1997-98$ & 161.88 & 193.12 & $2011-12$ & 277.90 & 257.13 \\
$1998-99$ & 167.98 & 203.61 & $2012-13$ & 258.04 & 264.77 \\
$1999-00$ & 180.69 & 209.8 & $2013-14$ & 239.59 & 2.34 \\
CAGR & 5.83 & 2.95 & CAGR & 2.79 & \\
\hline
\end{tabular}

Source: Reserve bank of India, Ministry of consumer affairs, food and public distribution government of India, www. Indiastat.com.

Note: 1 . Total food grains include Cereals (Rice, wheat), coarse cereals, and pulses. Total fertilizer consumption include N, P, K fertilizers)

2. Fertilizer consumption (In lakh tonnes) and Foodgrain production (In million tonnes) 
The data clearly shows that the growth rate in fertilizer consumption has reduced after 2000. While it has grown at an annual growth rate of $5.83 \%$ between 1986-87 and 1999-2000, it has grown at an annual growth rate of $2.79 \%$ between 2000-2001 and 201314. Food grain production also registered a marginal reduction in growth rate from $2.95 \%$ to $2.34 \%$ during the same period. But the growth rate of food grains production is always lower than the growth rate of fertilizer consumption. Between 1986-87 and 1999-2000 when fertilizer consumption recorded a growth rate of $5.83 \%$, food grains production increased by $2.95 \%$. Similarly, between 2000-2001 and 2013-14 when fertilizer consumption increased by $2.79 \%$, food grain production increased by $2.34 \%$ annual growth rate.

Co-integration analysis has been carried out to understand the long run relationship between consumption of chemical fertilizers and foodgrains production in India during the years from 1986-87 to 2013-14. The results are presented in the Table 2.

Table 2. Augmented Dicky- Fuller (ADF)

\begin{tabular}{lllll}
\hline Variables & \multicolumn{2}{c}{ T value } & \multicolumn{2}{l}{$\mathrm{P}$ value } \\
\hline & Level & First difference & Level & First difference \\
$\begin{array}{l}\text { Fertilizer } \\
\begin{array}{l}\text { Consumption } \\
\text { Foodgrain } \\
\text { production }\end{array}\end{array}$ & -1.245301 & -3.466556 & 0.6417 & 0.0160 \\
\hline
\end{tabular}

The ADF test result of first difference and intercept of the log form indicate that stationarity can be achieved at first difference. It implies the first order integration of fertilizer consumption and food grain production. Based on the integration at first order the Johnsen and Juselius co-integration was run. The results of the test are presented in Table 3.

Table 3. Johnsen and Juselius Co-integration test results Unrestricted Co-integration Rank Test (Trace )

\begin{tabular}{lllll}
\hline $\begin{array}{l}\text { Hypothesized } \\
\begin{array}{l}\text { Number. of } \\
\text { CE(s) }\end{array}\end{array}$ & Eigenvalue & $\begin{array}{l}\text { Trace } \\
\text { statistic }\end{array}$ & $\begin{array}{l}0.05 \\
\text { Critical } \\
\text { value }\end{array}$ & $\begin{array}{l}\text { Prob } \\
* *\end{array}$ \\
\hline None $^{*}$ & 0.392545 & 17.56502 & 15.49471 & 0.0241 \\
At most 1 & 0.065867 & 2.112240 & 3.841466 & 0.1461 \\
\hline
\end{tabular}

The test indicates 1 co integratingeqn(s) at the 0.05 level

* indicated that rejection of the hypothesis at the 0.05 level
Table 4. Unrestricted Co-integration Rank Test

\begin{tabular}{lcccc}
\hline $\begin{array}{l}\text { Hypothesized } \\
\text { Number of } \\
\text { CE(s) }\end{array}$ & Eigenvalue & $\begin{array}{l}\text { Maximum } \\
\text { Eigen } \\
\text { Stastitic }\end{array}$ & $\begin{array}{l}0.05 \text { Critical } \\
\text { value }\end{array}$ & Prob $^{* \star}$ \\
\hline None* $^{*}$ & 0.392545 & 15.45278 & 14.26460 & 0.0323 \\
At most '1' & 0.065867 & 2.112240 & 3.841466 & 0.1461 \\
\hline $\begin{array}{l}\text { Max-eigenvalue test indicates 1 cointegratingeqn(s) at the } 0.05 \text { level } \\
\text { * denotes rejection of the hypothesis at the 0.05 level } \\
\text { **MacKinnon-Haug-Michelis (1999) p-values }\end{array}$
\end{tabular}

The result shows that in both the tests the null hypotheses of no co-integrating vectors have been rejected against one co-integrating vectors. But we cannot reject null hypothesis of at most one co-integration vectors in the both the cases. (Because P value in trace test statistics and max-eigen value is greater than 5\%) Both the test results indicated the existence of at least one cointegrating vectors in the model at $1 \%$ of significance. The one co-integration vector implies that the fertilizer consumption and food grain production are related in the long run.

\subsection{Granger Causality}

Granger Causality is attempted to understand the two way relationship between consumption of chemical fertilizers and food grain production. Consumption of chemical fertilizers and food grain production are expected to be influencing each other. While increased fertilizer consumption leads to increased output, increased out is likely to influence the fertilizer consumption as increased return on agriculture increases affordability to purchase fertilizers.

Table 5. Pair wise Granger Causality Test

\begin{tabular}{llll}
\hline Null Hypothesis & Obs & f-Statistic & Prob \\
\hline $\begin{array}{l}\text { Fertilizer consumption- does not Granger } \\
\text { Causality FOODGRAIN_PRODUCTION }\end{array}$ & 28 & 7.39302 & 0.0029 \\
$\begin{array}{l}\text { Food grain Production- does not Granger } \\
\text { Causality FERTILIZER_CONSUMPTION }\end{array}$ & & 0.97198 & 0.3917 \\
\hline
\end{tabular}

The pairwise granger causality test (Table 5) has identified the causation of fertilizer consumption on foodgrains production at lag 2 . This shows that the fertilizer consumption has a significant influence on food grain production. On the other hand, food grain production does not seem to influence fertilizer consumption through its influence on incomes of the farmers. 


\section{Impact of Usage of Chemical Fertilizers on Land Degradation in India}

As observed earlier, food grain production always increased at a lower rate compared to the fertilizer consumption indicating that higher food grain production is achieved by higher doses of chemical fertilizers.

"Intensive agriculture, while increasing food production, has caused second generation problems in respect to the nutrient imbalance including greater mining of soil nutrients to the extent of 10 million tonnes every year, depleting soil fertility, deficiencies of secondary and micronutrients, decline of water table and its quality of water, decreasing organic carbon content and overall deterioration in soil health" (Ministry of Agriculture and Cooperation, \& Soil Health, 2012).

Soil degradation refers to decline in the quality of soil and it is a major constraint in achieving the sustainable agriculture without any decline in the production (Lal, 2015).

Several organizations and research institutes have estimated the land degradation in India, as per the statistics of Indian Council of Agricultural Research (ICAR, 2010), among the total geographical area 120.40 Million Hectare of land is degraded. According to National Bureau of Soil Survey \&amp; Land Use Planning (NBSS \&amp; LUP, 2004) estimation, among the total geographical area 146.8 Million Hectares of land is degraded by various sources.

Soil degradation is one of the serious issues facing by the country, it leads to negative impact on agricultural production and also increase in the cost of cultivation (Bhattacharyya et al. 2015).

\section{Government Initiatives}

The Government of Karnataka has taken several measures towards sustainable agriculture by giving more importance to organic farming. The Government of Karnataka has introduced "Karnataka State Organic
Farming Policy" during 2004 to promote the usage of organic fertilizers in agriculture.

The state introduced the first phase of Organic Village programme in order to bring around 100 ha of area in each district under organic farming. After the success of the first phase the scheme extended to each taluk in 2006-07. During 2010-11 it has been extended to convert another 100 ha of land into organic in each taluk level.

During 2013-14 the state introduced the Savayava Bhagya Yojane to encourage the organic farming, it is the extension of the organic village programme with few modifications, such as the scheme has started implementation at hobli level, the scheme is providing provisions for the development of marketing linkages to promote the usage of organic products.

During 2014-15 the state government has announced several programmes to encourage the organic farming like issue the certification of organic products, providing the publicity and spread the awareness about the scheme among farmers etc.

During the Tenth plan period the central government introduced the National Project on Organic Farming programme to promote organic farming in India. The main aim of this scheme is to encourage the organic farming, to increase the use of organic fertilizer, providing the short term certificate courses regarding organic system and farm management etc.

\section{Conclusion}

Fertilizer is one of the major inputs in the agricultural production. In order to meet the food requirements of the country Government has encouraged the use of chemical fertilizers by subsidizing the chemical fertilizers in the early years of independence. After attaining the food subsidy, the policy is oriented towards attaining sustainability in agriculture sector. Present study has analysed the trends in the fertilizer consumption and food grain production in India. The major finding of this study is that there is a long run relationship between fertilizer consumption and food grain produc- 
tion in India. Due to this, the fertilizer consumption increased at a higher rate in the early years. With the introduction of new agricultural policy where greater emphasis is given on promotion of organic cultivation, there is a considerable reduction in the growth rate of chemical fertilizer consumption after 2000-2001.

\section{Bibliography}

Bhattacharyya, R., Ghosh, B. N., Mishra, P. K., Mandal, B., Rao, C. S., Sarkar, Das, K. \& Franzluebbers, A. J. (2015). Soil Degradation in India: Challenges and Potential Solutions. Sustainability, 7(4), 3528-3570.

Gujarati, D. M., \& Sangeetha. (2007). Basic Econometrics Forth Edition. New Delhi: Tata McGraw- Hill Publishing Company Limited.

Hossain, M., \& Singh, V. P. (2000). Fertilizer use in Asian agriculture: implications for sustaining food security and the environment. Nutrient Cycling in Agro ecosystems, 57(2), 155-169.

Kinekar, B. K. (2011). Potassium fertilizer situation in India: Current use and perspectives. Karnataka Journal of Agricultural Sciences, 24(1).
Lal, R. (2015). Restoring Soil Quality to Mitigate Soil Degradation. Sustainability, 7(5), 5875-5895. Crossref.

Mazid, M., \& Khan, T. A. (2015). Future of bio-fertilizers in Indian agriculture: an overview. International Journal of Agricultural and Food Research, 3(3).

Ministry of Fertilizers, GoI. (2013). Indian Fertilizer Scenario.

Sachdeva, A. (2011). Nutrient Based Subsidy: Need and Impact on the Indian Agriculture. International Journal of Management and Strategy (IJMS) 2011, 2(3). Crossref.

Sharma, V. P., \& Thaker, H. (2009). Fertilizer subsidy in India: Who are the beneficiaries? Crossref

Sharma, V. P., \& Thaker, H. (2011). Demand for fertilizer in India: determinants and outlook for 2020. Indian Institute of Management.

Singh, J. (2013). Demand Projection of Chemical Fertilizer's Consumption In India: Determinants And Outlook For 2020. International Journal of Transformations in Business Management, 2(3).

Tandon, H. L. S., (2007). Soil Nutrient Balance Sheets in India: Importance, Status, Issues and Concerns, Better Crops India, 15-17. 